Bangladesh J. Bot. 42(2): 257-264, 2013 (December)

\title{
NOTES ON THE RUBIACEAE-5: FIVE NEW RECORDS FOR BANGLADESH
}

\author{
Sujit C Das, Pradip K Dev and M Atiqur Rahman* \\ Department of Botany, University of Chittagong, Chittagong 4331, Bangladesh
}

Key words: New records, Rubiaceae, Bangladesh

\begin{abstract}
Five species of the family Rubiaceae belonging to five genera are reported here as new records for Bangladesh. These species are Catunaregam longispina (Link) Tirveng, Galium pusillosetosum Hara, Ophiorrhiza eriantha Wight, Spermacoce exilis (Williams) Adams ex Burger et Taylor and Tarenna stellulata (Hook.f.) Ridl. In Bangladesh, occurrence of the genus Galium L. is also a new record. Each species is presented with updated nomenclature, commonly known synonyms, taxonomic description, ecology, geographical distribution, places of occurrence in Bangladesh, citation of examined specimens and supplementary notes. Illustrations with field photographs of these new records are also provided.
\end{abstract}

\section{Introduction}

Rahman and Das (2009) described a total of 170 taxa of the family Rubiaceae from the flora of Bangladesh. Further Das et al. (2009, 2012) and Das and Rahman (2010, 2011) added another 11 species to the account of Rubiaceae. Recent examination of the unidentified herbarium specimens of the Rubiaceae available at CAL, DACB, DUSH (Dhaka University Salar Khan Herbarium), BFRIH (Herbarium of Bangladesh Forest Research Institute) and BCSIRH (Bangladesh Council of Scientific and Industrial Research, Chittagong) and HCU (Herbarium of Chittagong University) revealed the determination of another five species of the family which have not been previously recorded from Bangladesh. These are, Catunaregam longispina (Link) Tirveng; Galium pusillosetosum Hara; Ophiorrhiza eriantha Wight; Spermacoce exilis (Williams) Adams ex Burger et Taylor and Tarenna stellulata (Hook.f.) Ridl. These species were collected from Chittagong, Dhaka, Dinajpur, Habigonj, Jamalpur, Khagrachari, Laxmipur, Moulvi Bazar, Mymensingh, Rangamati, Sherpur and Sylhet districts and have not been previously recorded from the area of Bangladesh in the relevant works of Roxburgh (1814, 1832), Wallich (18281849), Hook.f. (1882), Prain (1903), Brandis (1906), Heinig (1925), Kanjilal et al. (1939), Raizada (1941), Sinclair (1956), Khan and Banu (1972), Deb (1983), Kumar (1987), Rahman and Uddin (1997), Dey et al. (1998), Uddin and Rahman (1998), Uddin et al. (1998), Ridsdale (1998), Rahman (1999), Rashid et al. (1999), Mia and Rashid (2001), Das et al. (2002, 2004, 2009, 2012), Dutta and Deb (2004), Rahman and Das (2009) and Das and Rahman (2010, 2011).

The genus Galium L. was not also recorded from Bangladesh in any of these relevant works. Hence the genus Galium L. and these 5 species are new records for Bangladesh.

\section{Materials and Methods}

The plant specimens of the family Rubiaceae have been collected from different areas of Bangladesh, mainly from the forests of Chittagong, Hill Tracts districts, Cox's Bazar and greater Sylhet districts through repeated field trips under Aberdeen University-Chittagong University (AU-CU) Biodiversity Link Project since 1996 and lodged at the Herbarium of Chittagong University (HCU). The specimens of the Rubiaceae collected from the area of Bangladesh and preserved at CAL, DACB, DUSH, BFRIH, BCSIRH and HCU were examined by using Long

*Author for correspondence: <atiquerahman125@hotmail.com>. 
Arm Stereo Microscope. Unnamed specimens were identified and described by consulting relevant floristic literature of Hook.f. (1882), Prain (1903), Brandis (1906), Kanjilal et al. (1939), Deb (1983) and Dutta and Deb (2004). The identifications were confirmed also by matching with the named specimens of $\mathrm{ABD}, \mathrm{BM}, \mathrm{CAL}, \mathrm{E}$ and $\mathrm{K}$ as well as by consulting experts of those international herbaria.

The photographs of fertile specimens were taken during field trips and also from herbarium specimens.

A taxonomic enumeration with these five newly recorded rubiads is prepared. In the ennumeration, each species is cited with current nomenclature, commonly known synonyms, taxonomic description, ecology, geographical distribution, occurrence in Bangladesh, citation of voucher specimens and notes on taxonomy.

\section{Taxonomic enumeration}

1. Catunaregam longispina (Link) Tirveng. in Edinb. Jour. Bot. 53(1): 95 (1996); Springate in Fl. Bhutan 2(2): 790 (1999). Posoqueria longispina Link. in Enum. Pl. 1: 225 (1821). Gardenia longispina (Link) Sweet in Hort. Brit.: 197 (1826). Randia longispina (Link) DC., Prodr. 4:386 (1830).Type: Icones Roxburghianeae 1379 (K!).

(Fig. 1)

A small tree, up to $6 \mathrm{~m}$ long. Stems pubescent; armed with spines, spines up to $50 \mathrm{~mm}$ long. Stipules 2-5 mm long, ciliate, often lobulate. Petioles 10-15 mm long, pubescent. Lamina obovate, $7-11 \times 2.5-4 \mathrm{~cm}$, obtuse with a broad triangular cusp or subacute, cuneate at base, glabrescent, veins and margins hairy. Inflorescence fasciculate with 1-3 flowers; pedicels 4-12 mm long. Flowers 5-merous; calyx tube dilated, 3-5 mm long, pubescent externally and upper part internally; lobes narrowly oblong to broadly spathulate, $5-9 \times 1.5-5.5 \mathrm{~mm}$, acute or acuminate; corolla white, turning yellow, narrowly campanulate, tube up to $5.5 \mathrm{~mm}$ long, tomentose outside, lobes obovate, 7-9 $\times$ 5-7 mm, obtuse, apiculate; anthers up to $3 \mathrm{~mm}$ long, attached just above base to rim of corolla tube exerted. Fruits sub-globose, 28-40 $\times 22-30 \mathrm{~mm}$, yellow, calyx very rarely persistent; seeds oblong, reddish-brown, 3-5 mm diam. Fl. \& Fr. between April and August.
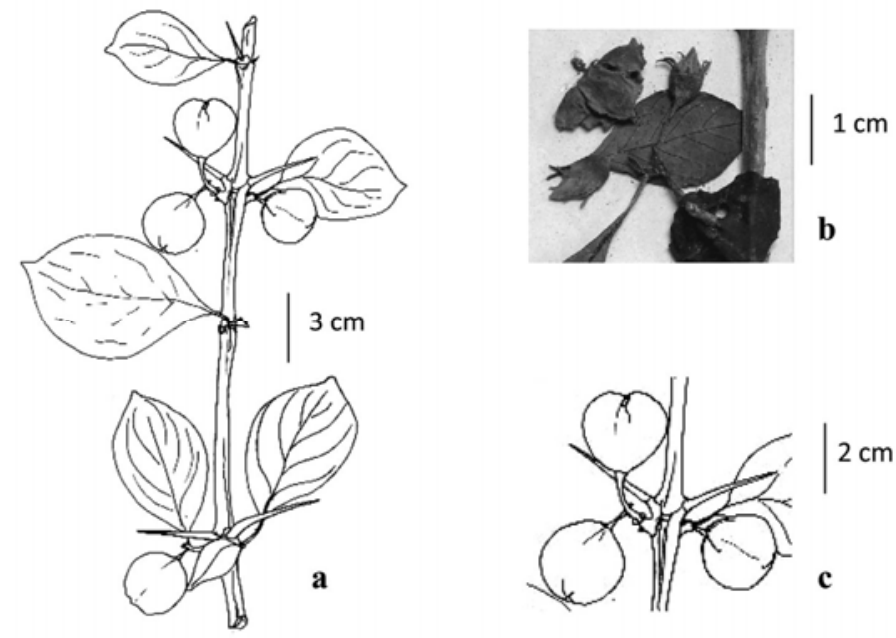

Fig. 1. Catunaregam longispina (Link) Tirveng. (a) habit, (b) inflorescence and (c) fruits.

Ecology: Grows in plain lands and hill slopes.

Geographical distribution: Bangladesh, Bhutan, India, Malaysia and Tropical East Africa. 
Occurrence in Bangladesh: Dhaka, Dinajpur, Habigonj, Jamalpur, Mymensingh and Sherpur.

Specimens examined: Dhaka district: Dhaka, locality not cited, 20.05.1975, C. B. Clarke 20088 (CAL); Chandra forest, 22.05.1983, Mia et al. M 932 (DACB). Dinajpur district: Sadar, 07.05.1875, C. B. Clarke 26434 (CAL). Habigonj district: Chanbari, Rema-Kalenga Wildlife Sanctuary, 16.03.1999, Zashim Uddin 538 (DUSH). Jamalpur district: Gajni forest, 05.05.1982, Mia et al. M 740 (DACB). Mymensingh district: Modhupur National Park, 17.06.1975, Huq 1281 (DACB); Majra Kura, Karsitala, 24.05.1989, Mia et al. M 2063 (DACB). Sherpur: Gajni forest, 27.04.1986, Huq and Mia 7686 (DACB); Gazni, 18.05.2007, Ershad 32 (DUSH).

Note: The genus Catunaregam Wolf. was previously known to represent in the flora of Bangladesh by two species: C. spinosa (Thunb.) Tirveng. and C. uliginosa (Retz.) Sivaraj (Rahman and Das 2009). This newly recorded species is characteristically different from other species of the genus for its axillary long spine and lobulate stipules.

2. Galium pusillosetosum H. Hara in Jour. Jap. Bot. 51(5): 134-135. f. 2. (1976); Hara et Gould in Enum. Fl. Pl. Nepal 2: 202 (1979); R.R. Mill in Fl Bhutan 2(2): 829-830 (1999). Type: E. Himalaya (not seen).

(Fig. 2)

A dwarf, slender, perennial herb. Stems 4-angled, ascending from procumbent base, hyalin or whitish winged, glabrous or with scattered spreading non-hooked setiform hairs. Stipules leafy, usually similar in size to the leaves, whorled. Leaves whorled, up to 6 per node, sessile or subsessile; lamina oblanceolate, 3.5-16 $\times$ 0.8-4.2 mm, apex cuspidate or mucronate, base attenuate; membranous, thin, both surfaces hairy. Inflorescence terminal cymes on short opposite axillary branches, few-flowered. Flowers 4-merous; pedicels up to $4 \mathrm{~mm}$ long, divaricate, glabrous; corolla up to $2.5 \mathrm{~mm}$ diam, spreading, reddish or purplish, lobes ovate, shortly acuminate, scabrid apically within; stamens up to 4, exserted, anthers dorsifixed; stigma forked, capitate, or clavate, styles attenuate from the ovary, with numerous dense, straight, subappressed, whitish non-hooked hairs. Fruits indehiscent, drupe, 2 seeded; seeds winged. Fl. \& Fr. from April to August.

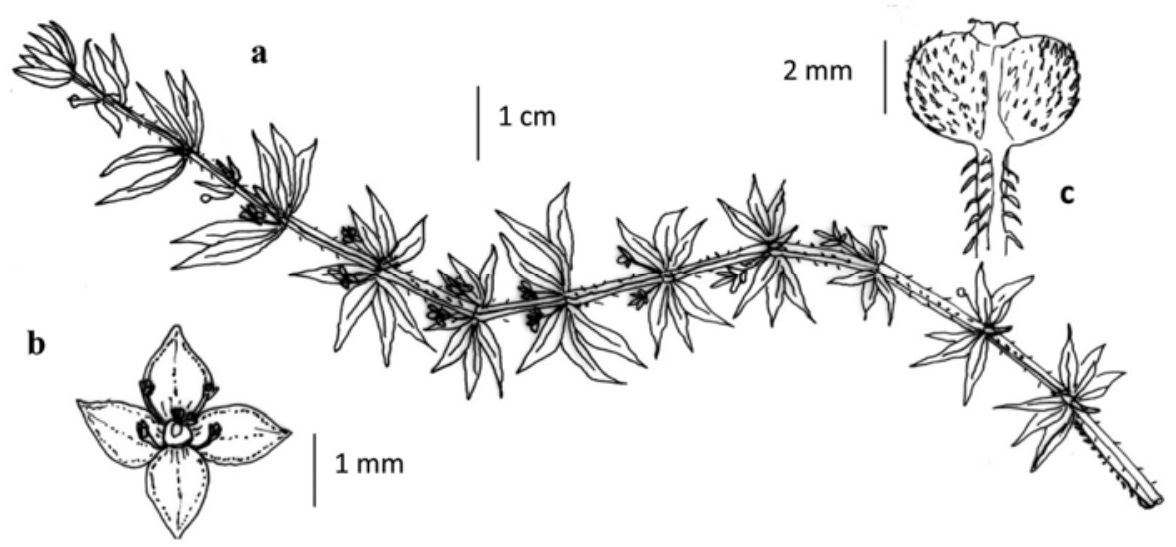

Fig. 2. Galium pusillosetosum Hara (a) habit, (b) flower and (c) fruit.

Ecology: Grows in open grass lands.

Geographical distribution: Australia, Bangladesh, Bhutan, China, India and Nepal.

Occurrence in Bangladesh: Chittagong and Dhaka. 
Specimens examined: Chittagong district: Baluchara, 03.04.1998, M. Yusuf 1030 (BCSIRH). Dhaka district: Dhanmondi, 18.07.1988, Mahabuba Halim s. n. (DACB).

Note: The genus Galium L. has not been recorded previously from Bangladesh.

3. Ophiorrhiza eriantha Wight in Icon. Pl. Ind. Orient. 3: t. 1067 1846); Hook.f., Fl. Brit. Ind. 3: 81 (1880); Deb et Mondal in Bull. Bot. Surv. India 39: $42-44$ (1997). Type: India, Courtallum, August 1835, Wight s.n. (K!).

(Fig. 3)

Herb or under shrub. Stems erect, suffruticose, branched, pubescent when tender, glabrous with age. Stipules 0.5-1.5 $\times 0.2 \mathrm{~cm}$, lanceolate, often bifid, glabrous, sometimes puberulous. Petioles $0.5-3 \mathrm{~cm}$ long, glabrous or puberulous. Lamina elliptic-lanceolate, 4-19 $\times$ 2-7.5 cm, thin, membranous, apex acuminate, base tapering, puberulous on the nerves beneath; lateral nerves up to 16 on either side, closed. Inflorescence terminal corymbose cymes, up to $5 \mathrm{~cm}$ across, contracted, branches erect, villous, peduncles 1.7$5.5 \mathrm{~cm}$ long, villous. Bracts persistent, $10-17 \mathrm{~mm}$ long, narrowly linear. pubescent; bracteoles persistent, 6-10 mm long, narrowly linear, pubescent. Flowers 19-27 mm long, pinkish-white, sometimes greenish-white, and fragrant; pedicels 1-2 mm long, pubescent; hypanthium 2-2.3 × 1.8-2 mm, obovoid, pubescent; calyx lobes $1.5-2 \times 0.8-1 \mathrm{~mm}$, subulate, acute, pubescent; corolla 17-24.8 mm long, infundibuliform, villous outside, glabrous within; lobes 5-7 $\times 2-3.5 \mathrm{~mm}$, broadly ovate, acute; stamens adnate to the middle of corolla tube, inserted, filaments $2-2.8 \mathrm{~mm}$ long, anthers 3-3.25 mm long, oblong-linear; stigma 2-lobed, 2.5-3.3 mm long, lobes lanceolate, acute, glabrous, style short, glabrous, ovary 1.8-2 × 1.6-1.8 mm, obovoid, disc 0.75-1 mm high. Capsules 2.5$3.3 \times 7-8.5 \mathrm{~mm}$, pubescent, locules ovate-oblong, tips slightly inclined outwards; seeds $0.5-0.6 \times 0.4-0.5 \mathrm{~mm}, 4-6$ angular, glabrous, deep brown. Fl. \& Fr. from February to October.
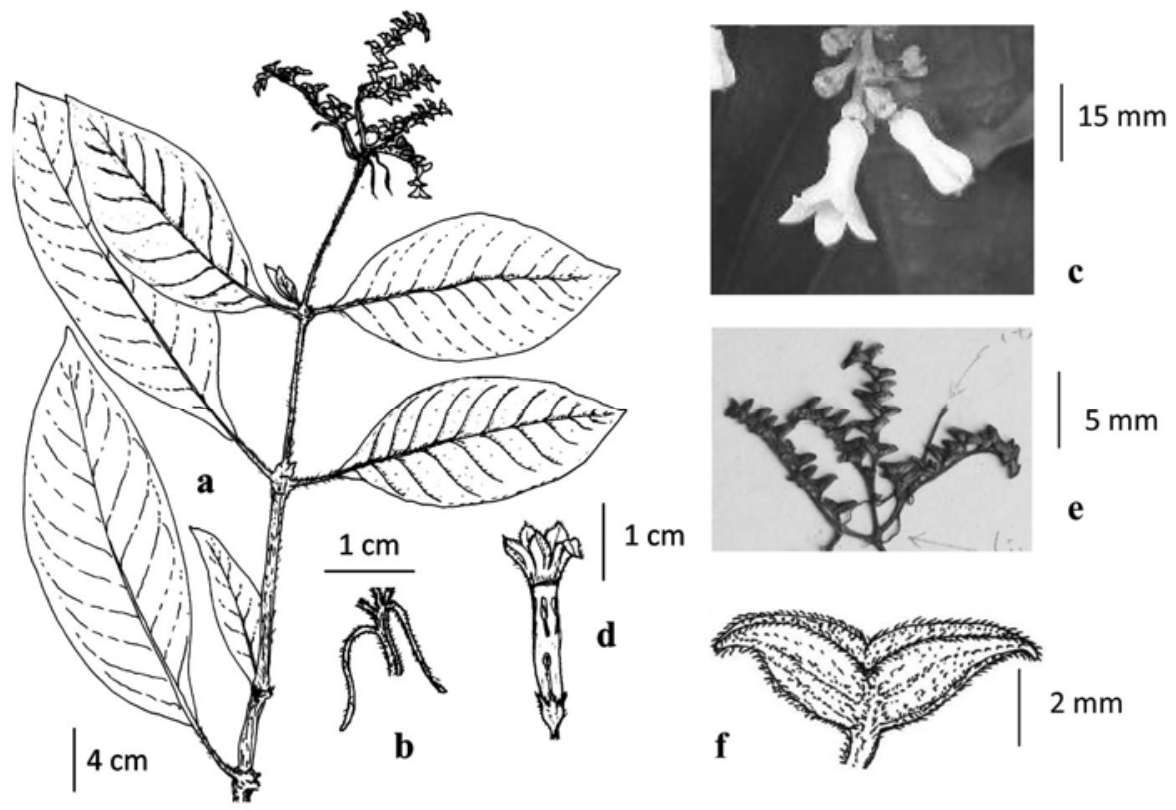

Fig. 3. Ophiorrhiza eriantha Wight (a) habit, (b) linear bract, (c) flower, (d) flower showing adnate stamen to middle of corolla, (e) infrutescence and (f) fruit. 
Ecology: Grows on laterite and loamy soil in crevices of rocks in shady moist places of hilly areas.

Geographical distribution: Bangladesh and India.

Occurrence in Bangladesh: It has been collected from Khagrachari district only.

Specimens examined: Khagrachari district: Shilchari, Alu tila, 05.08.1997, Rahman et al. 1718 (HCU).

Note: The genus Ophiorrhiza L. was reported to be represented in the flora of Bangladesh by seven species (Rahman and Das 2009). This species seems to be very closer to O. fasciculata but differs for its closed leaf nerves, narrowly linear (up to $17 \mathrm{~mm}$ long) persistent bracts and subulate calyx lobes.

4. Spermacoce exilis (L.O.Williams) C.D. Adams in Fieldiana, Bot. n.s. 33: 316. f. 5 (1993). Borreria exilis L.O.Williams in Phytologia 28(3): 227 (1974) based on B. gracilis L.O. Williams in Phytologia 26(6): 487 (1973); S. mauritiana Gideon in Kew Bull. 37: 547 (1983); S. decandollei Deb et Dutta, Jour. Econ. Tax. Bot. 5(5): 1044 (1984). Type: Mauritius, Sieben $144 \mathrm{G}$, microfische.

(Fig. 4)

Decumbent or procumbent herb, branched, up to $40 \mathrm{~cm}$ tall. Stems with crisped hairs. Stipules $2 \times 1 \mathrm{~mm}$, bearing up to 7 fimbriates, $1-3 \mathrm{~mm}$ long. Petioles up to $8 \mathrm{~mm}$. long, with scattered hairs. Lamina elliptic to elliptic-lanceolate, $0.4-3.8 \times 0.3-1.8 \mathrm{~cm}$, apex rounded to acute, concavely narrowed into the petiole at base, glabrous on both surfaces, margines hairy, pubescent on the main nerves beneath. Inflorescence small, in few-flowered clusters at many of the nodes, attaining 3-6 $\mathrm{mm}$ in diameter at fruiting stage; bracteoles stipule-like with $1.8-2 \mathrm{~mm}$ long fimbritaes; calyx tube $0.5 \mathrm{~mm}$ long, transversely oblong, lobes two, $0.6-0.8 \mathrm{~mm}$ long, ciliate; corolla white, tube $0.3 \mathrm{~mm}$ long, lobes triangular with a few short hairs inside; anthers situated just above the sinuses of the corolla lobes; stigma $0.2 \mathrm{~mm}$ wide, styles $0.2 \mathrm{~mm}$ long. Fruits oblong, compressed, 2-lobed, finely transversely wrinkled and very shortly pubescent; seeds oblongellipsoid, $0.7-0.8 \times 0.4 \mathrm{~mm}$, chestnut-brown, strongly reticulate with raised ribs, grooved ventrally. Fl. \& Fr. throughout the year.

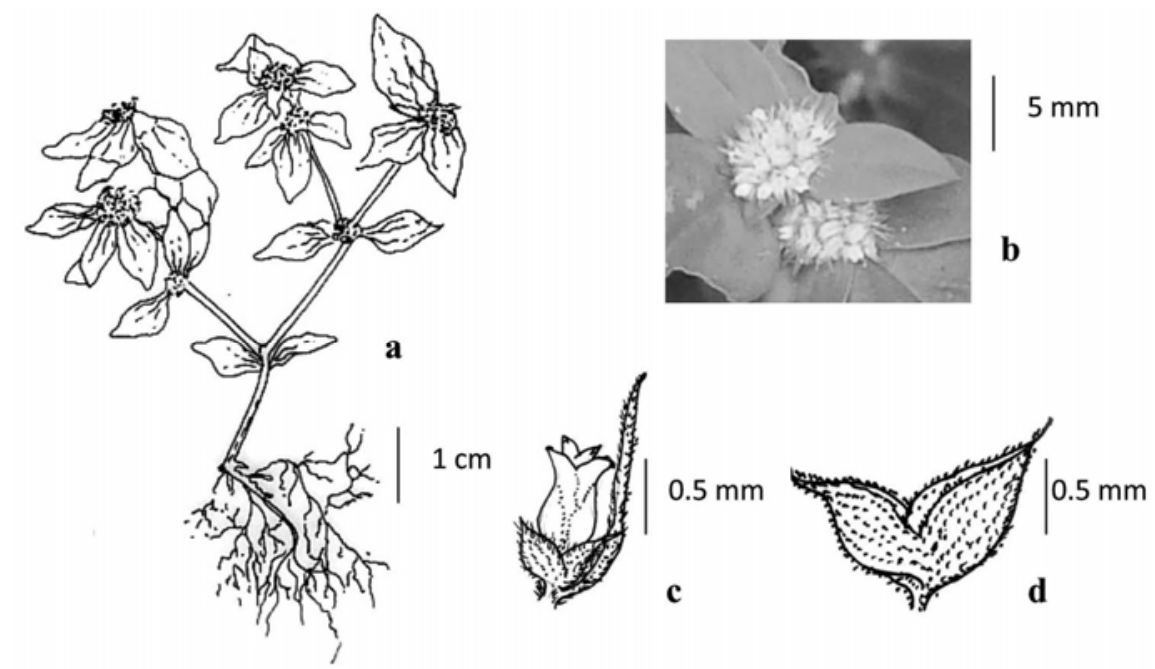

Fig. 4. Spermacoce exilis (Williams) Adams ex Burger \& Taylor (a) habit, (b) inflorescence (c) flower with bracteole and (d) fruit. 
Ecology: Plain land along roads, hill slopes and forest periphery.

Geographical distribution: Bangladesh, Bhutan, India, Java, Malay Peninsula, Myanmar, South American countries and Taiwan.

Occurrence in Bangladesh: Chittagong, Cox’s Bazar, Laksmipur, Moulvi Bazar and Sylhet.

Specimens examined: Chittagong district: Kumira, Dardorir chara, 20.10.2006, Sujit and Rumen 6505 (HCU). Cox's Bazar district: Himchari, Bhangamura, 29.06.1997, Rahman and Uddin 1417A, 1445A (HCU). Laksmipur district: Ramgonj, 22.09.2009, Sujit 305 (HCU). Moulvi Bazar district: Srimongal, Tea resort, 28.09.2008, Sujit 6518 (HCU); Bhanugach road, 28.09.2008, Sujit 6529 (HCU). Sylhet district: Tibbi College campus, 22.10.1986, H 7951 (DACB); Deari, 16.05.2005, D. K. Majumder s. n. (HMCCS).

Note: The genus Spermacoce L. is represented in the flora of Bangladesh by 3 species (Rahman and Das 2009). This species is remarkably differs from others by its 2-lobed calyx and capsule and included or slightly exceeding stamens and style on top of corolla tube.

5. Tarenna stellulata (Hook.f.) Ridl., Fl. Malay Penins. 2: 106 (1923). Webera stellulata Hook.f., Fl. Brit. Ind. 3: 104 (1880); Ixora stellulata (Hook.f.) Kuntze in Revis. Gen. Pl. 1: 278 (1891). Syntype: Penang, Griffith 3086 (K!).

(Fig. 5)

A shrub to treelet, up to $4 \mathrm{~m}$ tall. Branches hairy. Stipules triangular, 0.2-0.5 $\times 0.1-0.3 \mathrm{~cm}$, sometimes with lateral wings, with cuspidate or caudate apex, drying completely brown. Petioles up to $6 \mathrm{~mm}$ long. Lamina elliptic to lanceolate, c. $6 \times 4 \mathrm{~cm}$, chartaceous, upper surface glabrous, turning black, or hairy only on midribs, lower surface, dark brown with scattered tiny hairs and rough to the touch, tertiary nerves on lower leaf surface distinct, leaves drying black above, secondary veins less than 13 pairs. Inflorescence erect and usually less than $8 \mathrm{~cm}$ long. Flowers 2 $\mathrm{cm}$ long, pubescent; calyx lobes broadly triangular, tomentose, margin not ciliated; corolla lobes as long as or longer than the tube, with apiculate tips and ciliate margins. Fruits up to $15 \mathrm{~mm}$ diameter with scar of deciduous calyx, globose. Fl. \& Fr. September to November.

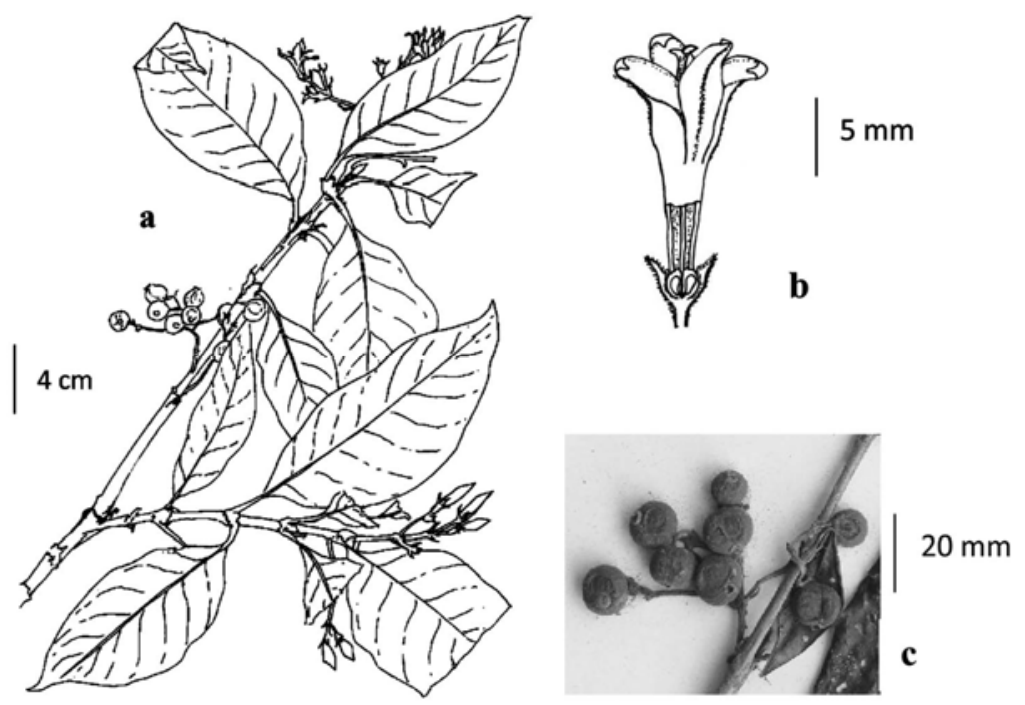

Fig. 5. Tarenna stellulata (Hook.f.) Ridl. (a) habit, (b) flower and (c) infruitescence. 
Ecology: Mountain forest at $1200 \mathrm{~m}$.

Geographical distribution: Bangladesh, Penang and S. Thailand.

Occurrence in Bangladesh: Chittagong district only.

Specimens examined: Chittagong district: Sitakunda, Chandranath hill, 11.10.1998, Rahman et al. 3693 (HCU).

Note: The genus Tarenna was known to occur in Bangladesh with 4 species (Rahman and Das 2009). This species is different from others by its 7-9 pairs of nerves in the lamina, shorter corolla lobes and solitary ovule in each locule.

\section{Acknowledgement}

Authors are grateful to the authorities of E, K, CAL, DACB, DUSH, BFRIH, BCSIRH and HCU for allowing them to use their specimens and libraries.

\section{References}

Brandis D 1906. Indian Trees. Bishen Singh Mahendra Pal Singh, Dehra Dun, India. pp. 364-398.

Das SC, Rahman MA, Rashid MH and Wilcock CC 2002. Notes on the Rubiaceae 1: Four new records for Bangladesh. Bangladesh J. Plant Taxon. 9(1): 67-75.

Das SC, Rahman MA, Rashid MH and Wilcock CC 2004. Notes on the Rubiaceae 2: Five new records for Bangladesh. Bangladesh J. Plant Taxon. 11(1): 9-17.

Das SC, Rashid MH and Rahman MA 2009. Taxonomic revision of the genus Pavetta L. (Rubiaceae) of Bangladesh. Plant Archives 9(2): 813-820.

Das SC and Rahman MA 2010. Notes on the Rubiaceae 3: Five new records for Bangladesh. Bangladesh J. Bot. 39(2): 215-222.

Das SC and Rahman MA 2011. Taxonomic revision of the genus Morinda L. (Rubiaceae) in Bangladesh. Bangladesh J. Bot. 40(2): 113-120.

Das SC, Dev PK and Rahman MA 2012. Notes on the Rubiaceae 4: Five new records for Bangladesh. Bangladesh J. Bot. 41(1): 21-28.

Deb DB 1983. The Flora of Tripura state. 2: 37-90. Today and Tomorrow's Printers and Publishers. India.

Dey CK, Rahman MA and Wilcock CC 1998. An enumeration of the tree species of Chittagong district. In: Biodiversity Bulletin Bangladesh. University of Chittagong. pp. 81.

Dutta R and Deb DB 2004. Taxonomic revision of Hedyotis L. (Rubiaceae) in Indian sub-continent. Botanical Survey of India, Kolkata, India.

Heinig RL 1925. List of plant of the Chittagong collectorate and Hill Tracts. Darjeeling, India. pp. 33-36.

Hooker JD 1882. Flora of British India 3: 17-210. L. Reeve and Co. London.

Kanjilal UN, Kanjilal PC and Das A 1939. Flora of Assam 3: 11-95. (reprint 1982) Calcutta, India.

Khan MS and Banu F 1972. A taxonomic report on the Angiospermic flora of Chittagong Hill Tracts 2. In: J. Asiat. Soc. Beng. 17(2): $59-88$.

Kumar D 1987. Forest flora of Chittagong. Bangladesh Forest Research Institute, Chittagong, Bangladesh.

Mia MMK and Rashid MH 2001. Richardia scabra L. (Rubiaceae) - A new angiospermic genus and species record for Bangladesh. Bangladesh J. Plant Taxon. 8(1): 97-100.

Prain D 1903. Bengal Plants 1: 400-425 (Ind. Repr. 1963). Botanical Survey of India, Kolkata.

Rahman MA 1999. Some new angiospermic records for Bangladesh. In: Biodiversity Newsletter, Bangladesh 3(2): 1 .

Rahman MA and Das SC 2009. Rubiaceae. In: Ahmed, Z.U., Hassan, M.A., Begum, Z.N.T., Khondker, M., Kabir, S.M.H., Ahmed, M. and Ahmed, A.T.A. (eds.). Encyclopedia of Flora and Fauna of Bangladesh. 10: 38-159. Asiatic Society of Bangladesh, Dhaka. 
Rahman MA and Uddin SB 1997. Angiospermic Flora of Sitakund in Chittagong. Bangladesh J. Plant Taxon. 4(1): 17-36.

Raizada MB 1941. On the flora of Chittagong. The Indian Forester 67(5): 245-254.

Rashid MH, Rahman MA and Khan MS 1999. A checklist of the Rubiaceae of Bangladesh. Bangladesh J. Plant Taxon. 8(2): 75.

Ridsdale CE 1998. Rubiaceae. In: Dassanayake, A revised handbook to the Flora of Ceylon 12: 141-343.

Roxburgh W 1814. Hortus Bengalensis (nom. nud.). Calcutta. pp. 10-11.

Roxburgh W 1832. Flora Indica. 1:362-720. Mission Press, Serampore, Calcutta, India.

Sinclair J 1956. The Flora of Cox’s Bazar, East Pakistan. In: Bull. Bot. Soc. Beng. 9(2): 84-116. Calcutta, India.

Uddin SB and Rahman MA 1998. Angiospermic flora of Himchari National Park, Cox’s Bazar. Bangladesh J. Plant Taxon. 6(1): 31-68.

Uddin SN, Khan MS, Hassan MA and Alam MK 1998. An annotated checklist of angiospermic flora of Sita pahar at Kaptai in Bangladesh. Bangladesh J. Plant Taxon. 5(1): 13-46.

Wallich N 1828-1849. A numerical list of dried specimens of plants in the East Indian Company’s Museum (Wall. Cat.) ined.

(Manuscript received on 12 September, 2012; revised on 1 October, 2013) 